\title{
Recovery from disturbance of coral and reef fish communities on the Great Barrier Reef, Australia
}

\author{
M. J. Emslie*, A. J. Cheal, H. Sweatman, S. Delean \\ Australian Institute of Marine Science, PMB No. 3, Townsville Mail Centre, Townsville, Queensland 4810, Australia
}

\begin{abstract}
Coral reefs are consistently and increasingly subject to acute disturbance events that often lead to a reduction in live coral cover with concomitant effects on the diversity and abundance of coral reef fishes. Here we examine changes in both hard coral and reef-fish assemblages over $15 \mathrm{yr}$ following major losses of coral from exposed reefs in 2 widely separated sectors of the Great Barrier Reef (GBR), Australia. While the rate and extent of increase in coral cover (from $<15$ to $>60 \%$ ) was similar in the 2 sectors, differences in the rugosity of the underlying reef framework influenced the structure of fish communities. Soon after disturbance, when coral cover was very low and the limestone reef framework constituted most of the surface relief, the relatively featureless substrate on reefs of the southern sector supported fewer fish species than reefs of the northern sector, which had a more rugose substrate. At first, northern reefs also had a higher proportion of herbivorous fish species, presumably because the more complex reef surface provided shelter and allowed them to exploit the abundant algal turf. With increasing coral cover, coral colonies came to provide most of the surface relief in both sectors, and species richness and the trophic structure of the fish communities converged. Variation in the cover of branching corals explained significant variation in the fish communities in both sectors over time, reflecting the importance of this growth form to small coralassociated fishes. These results show that the recovery of the coral community and the complexity of underlying reef framework interact to determine the functional structure of associated fish communities despite differences in regional settings.
\end{abstract}

KEY WORDS: Coral disturbance · Coral recovery - Fish communities · Trophic · Great Barrier Reef · Storm damage Resale or republication not permitted without written consent of the publisher

\section{INTRODUCTION}

Disturbance plays a major role in structuring many ecological communities including grasslands (Collins et al. 1995) and forests (Connell 1978, Hiura 1995), and particularly in marine systems that are primarily limited by space, such as rocky shores (Sousa 1979, Underwood 1999) and coral reefs (Connell 1978, Hughes \& Jackson 1985, Hughes 1989, Done 1992, Bythell et al. 2000). The short-term effects of disturbance can be wholesale destruction of major habitat components (Woodley et al. 1981, Halford et al. 2004, Gardner et al. 2005), resulting in reversion to earlier successional states (e.g. Colgan 1981). Re-colonization and growth may lead to recovery of the pre-disturbance community (resilience) or result in a phase shift to an alternate and persistent community (Knowlton 1992). However, these phase shifts may not persist indefinitely, and there is evidence for phase shift reversals on some Caribbean reefs (Edmunds \& Carpenter 2001, Idjadi et al. 2006, Mumby et al. 2007).

Disturbances on coral reefs range from local physical disturbances such as storm waves, which have differential effects on sections of the same reef and usually last a few days (Cheal et al. 2002, Halford et al. 2004, Adjeroud et al. 2005) to larger scale and longer term phenomena such as outbreaks of the crown-of-thorns starfish Acanthaster planci and coral bleaching, which affect numerous reefs within a sector and persist for weeks to years (Moran 1986, Sano et al. 1987, Berkelmans \& Oliver 1999, Marshall \& Baird 2000, Sano 2000, Wilkinson 2004, Graham et al. 2006). The major impact 
of large storms is to reduce cover of live hard corals through physical breakage of the coral skeletons. Depending on the severity of the storm, the resulting coral rubble may be washed away from the site, leaving a bare substrate (Halford et al. 2004). This contrasts with disturbances such as coral bleaching and outbreaks of $A$. planci that can also lead to high coral mortality but leave the dead coral skeletons intact until storms and bioerosion eventually reduce them to rubble (Sano et al. 1987, Sano 2000). In these cases coral skeletons may still provide shelter and refuges for reef fishes for some time after the disturbance. While the magnitude and spatial scale of damage vary with the type and duration of disturbance, a decrease in live coral cover is the usual result. The capacity of a reef to recover depends on the historical coral cover, the type and history of disturbances (multiple stressors can have additive effects), the extent of damage and demographic processes such as recruitment and growth (Colgan 1981, Hughes \& Connell 1999).

Whilst disturbances may radically alter the benthic community, effects on associated reef-fish communities may not always be obvious. Natural disturbance events rarely cause mortality of coral reef fishes directly (Harmelin-Vivien 1994), but the associated habitat degradation may affect fish communities indirectly. Experimental reductions of living coral cover have been shown to lead to changes in fish community structure, although these were largely due to changes in abundance of a handful of coral-associated species, and most species were unaffected (Lewis 1997, 1998, Jones \& Syms 1998, Syms 1998, Syms \& Jones 2000). Changes in abundances of many species resulted from the reduction of structural complexity and loss of microhabitats and shelter as dead coral skeletons collapsed, rather than from the loss of living coral per se (Lewis 1997, 1998). Changes in the structure of fish communities following natural disturbances have been variable; short-term effects have ranged from minimal impact to wholesale changes in the community (Sano et al. 1987, Munday et al. 1997, Sano 2000, Adjeroud et al. 2002, Booth \& Beretta 2002, Cheal et al. 2002, Halford et al. 2004, Bozec et al. 2005).

There have been many studies of short-term responses of fish communities to disturbance and a few longer term studies showing that reef-fish diversity and abundance decline with declining coral cover (Jones et al. 2004, Garpe et al. 2006, Graham et al. 2006, Wilson et al. 2006). However, very few studies have been sustained for long enough to record changes in reef fish assemblages as the coral recovered, and results to date are variable. In one case where reef fish communities were studied following habitat degradation and recovery, the fish community recovery closely tracked the recovery of the coral community on reefs of the south- ern GBR (Halford et al. 2004). Seven years after the disturbance, the fish community closely resembled the pre-disturbance community in 2 metrics: species richness and abundance, suggesting that the community was resilient. These results contrast with a study in Moorea where hard coral cover and butterflyfish abundance recovered to pre-disturbance levels, but the preand post-disturbance assemblages of butterflyfishes included quite different species (Berumen \& Pratchett 2006). This highlights the need to give careful consideration to the metrics used in attributing resilience or recovery of reef communities.

There is evidence to suggest that live coral cover is important for many fish species, such as obligate corallivores (Sano et al. 1987, Sano 2000, Pratchett 2007) or those intimately associated in their early life history (Jones et al. 2004). However, there is also evidence that topographic complexity is important for the provision of shelter (see Sano 2000). Topographic complexity is defined here as the sum of complexity afforded by living and dead coral (structural complexity) and complexity of the underlying reef matrix (substrate complexity). It is often unclear whether structural or substrate complexity is more important in determining fish communities, and we avoid this confusion by simply referring to topographic complexity, which encompasses both.

The present study tracked annual changes in species richness and trophic structure of reef fish communities on reefs in 2 widely separated sectors of the GBR (>1200 km apart) after separate storms decimated the coral communities. The fronts of reefs in both sectors were dominated by tabulate Acropora spp. (Ninio \& Meekan 2002). Trajectories of coral cover recovery and resultant benthic communities were very similar in the 2 sectors. This presented an opportunity to assess whether the trophic structure of fish communities, separated by $>1000 \mathrm{~km}$ in different regional settings, that were unlikely to be linked by larval dispersal (James et al. 2002, Cowen et al. 2006) responded similarly to comparable patterns of coral recovery. Specifically, we wanted to determine: (1) the recovery trajectories of coral communities in each sector; (2) how the trophic structure of fish communities tracked changes in live coral cover in each sector and (3) the role of habitat complexity in the recovery of fish communities.

\section{MATERIALS AND METHODS}

Seven reefs were surveyed annually between 1993 and 2005 by the Long Term Monitoring Program (LTMP) at the Australian Institute of Marine Science (AIMS). Three reefs, 'Carter', 'No Name' and 'Yonge', were located in the northern GBR $\left(\sim 14^{\circ} \mathrm{S}\right)$ on the edge 
of the continental shelf in the Cooktown/Lizard Island sector (hereafter CL) (Fig. 1). The other 4 reefs, 'Broomfield', 'Lady Musgrave', 'One Tree' and 'Wreck', were located in the southern GBR $\left(\sim 23^{\circ} \mathrm{S}\right)$ on the outer shelf of the Capricorn/Bunker sector (hereafter CB) (Fig. 1). CL reefs slope steeply (40 to $70^{\circ}$ ) from the crest to a narrow shelf at depths of ca. $30 \mathrm{~m}$. The substrate of the slope contains many holes, gullies, overhangs and caves, which enhance topographic relief. The $4 \mathrm{CB}$ reefs have shallow slopes $\left(0\right.$ to $\left.20^{\circ}\right)$. Here the substrate consists of a hard, flat, featureless reef pavement with low relief. Occasional rubble-filled gullies run down the reef slope into deeper water. Halford et al. (2004) investigated resilience of reef fish communities on $\mathrm{CB}$ reefs by comparing pre- and post-disturbance communities using the first $6 \mathrm{yr}$ of data from the LTMP. We build on that work by including an additional 6 yr of post-disturbance data for $\mathrm{CB}$ reefs and by comparing long-term patterns of recovery on CB reefs to those of another set of disturbed reefs (CL) $1200 \mathrm{~km}$ to the north. Furthermore, the present study focuses entirely on the response of fish communities to coral recovery.

The same methods were used to survey sites in a standard habitat, the reef slope on the northeast flanks, on each of the 7 reefs. Three sites were sampled on each reef, with 5 permanently marked $50 \mathrm{~m}$ transects running parallel to the reef crest at 6 to $9 \mathrm{~m}$ depth in each site. The benthic community was described from digital video recordings of a $30 \mathrm{~cm}$ swathe along each transect. Forty evenly-spaced frames from each of these video transects were projected, and the ben-

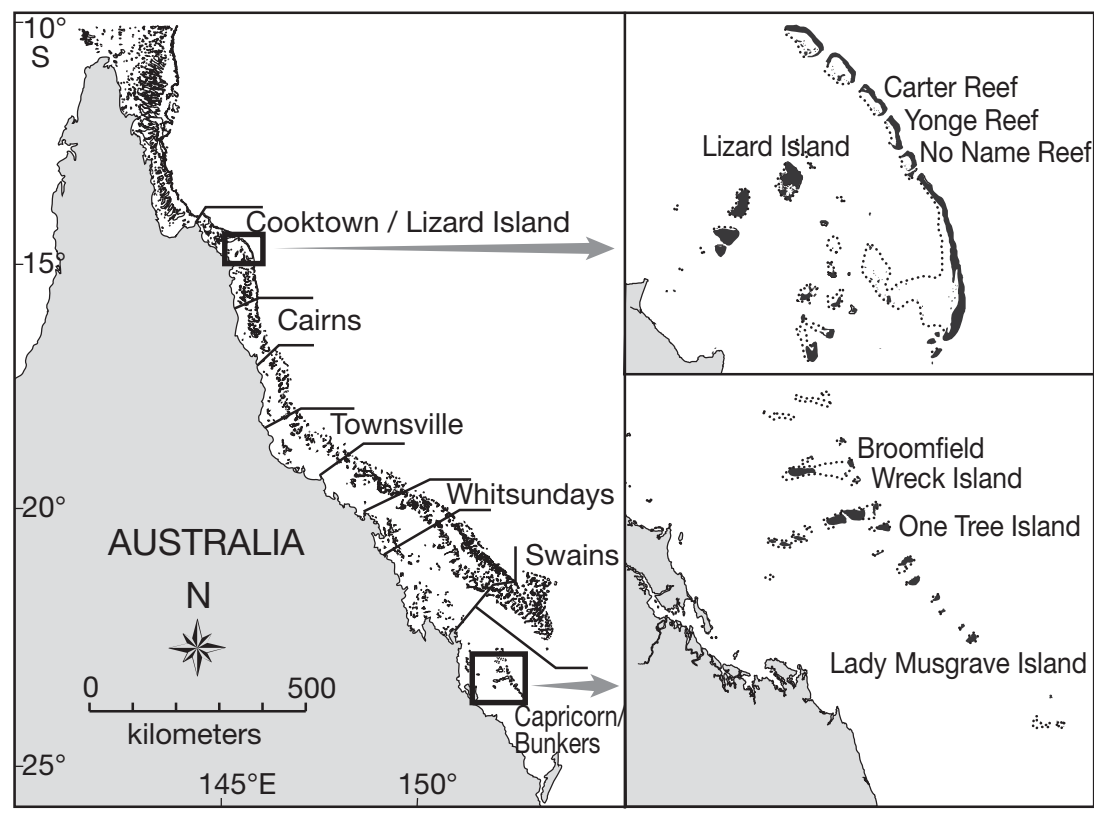

Fig. 1. Great Barrier Reef, Queensland, Australia, showing the locations of the reefs in the Cooktown/Lizard Island and Capricorn/Bunker sectors. Black: reefs; dotted lines: shoals thic organisms beneath 5 points on each frame were identified to the highest possible taxonomic resolution yielding 200 points transect ${ }^{-1}$. Since it was not always possible to identify benthic organisms to the species level, organisms were grouped by growth form for analysis. Initial analyses revealed that tabulate and branching Acropora spp. were the only groups to increase substantially during the present study; cover of all other hard coral life form groups varied little through time. Branching and tabulate Acropora spp. were also the most dominant, habitat-forming hard corals on all reefs. Thus subsequent analyses were focused on the percent cover of 5 broad benthic groups: (1) total hard coral, (2) tabulate Acropora spp., (3) branching Acropora spp., (4) coralline algae and (5) turf algae. Data were summed to the reef level and then averaged for each sector.

Topographic complexity was estimated retrospectively for all transects at each reef in each of 4 survey years (1993, 1997, 2000 and 2005) using $360^{\circ}$ video panoramas of the reef slope recorded at the start of each transect. Topographic complexity was estimated using a scale between 0 (least complex) and 5 (most complex) (Polunin \& Roberts 1993, Wilson et al. 2007) and then averaged over all transects on each reef in each year. This method can be done retrospectively and has been shown to correlate with other measures of complexity (Wilson et al. 2007). A single observer made all the estimates within a period of $1 \mathrm{wk}$.

Reef fishes from a list of 210 species (including species from Acanthuridae; Chaetodontidae; Labridae; Lethrinidae; Lutjanidae; Pomacentridae; Scaridae; Serranidae; Siganidae and Zanclidae that occur on the GBR) were counted on the fixed transects using underwater visual census. Two transect widths were used: $50 \times 1 \mathrm{~m}$ belts for the Pomacentridae and $50 \times 5$ $\mathrm{m}$ belts for the remaining families. Because the surveys spanned the recruitment season, only fishes in the 1+ year class or older were recorded. For each species, 0+ fishes were identified by their size and by any distinctive juvenile coloration. Despite observers being very experienced, some subjective judgment was used in underwater estimations of cutoff lengths for $0+$ fishes. Therefore cross-calibration among observers was performed regularly to ensure consistency.

Comparisons of fish community changes between the $\mathrm{CB}$ and $\mathrm{CL}$ 
reefs were potentially difficult because the species pool for CL reefs was $\sim 30 \%$ larger than for CB reefs (AIMS LTMP unpubl. data). To allow valid spatial comparisons, species were classified into 6 broad trophic groups based on published information (Sano et al. 1984, Bellwood \& Choat 1990, Froese \& Pauly 2006) and field observations. The tropic groups were: herbivores (included the detritus suckers e.g. Ctenochaetus spp., which also ingest algae, blue-green algae and diatoms), sessile benthic feeders (species that feed on sessile benthic invertebrates other than hard coral), corallivores (obligate hard coral feeders), benthic planktivores (fishes intimately associated with the benthos that supplement their benthic diet with plankton), planktivores (species that forage in the water column for plankton) and predators (piscivores and mobile nekton feeders) (Appendix 1). The numbers of individuals in these trophic groups were summed for each reef in each year, then converted to relative abundance ( $\%$ of total community) and averaged over the reefs to estimate sector means. Ninety-five percent confidence intervals were also calculated.

Linear mixed effects models (Pinheiro \& Bates 2000) were used to investigate spatial and temporal differences in reef fish abundances, trophic group abundance, species richness and benthic cover. Response variables were overall relative abundance and species richness of reef fishes (constrained by the species list). Topographic complexity of the reef slope and percent cover of the 5 benthic groups were included in the model. Mixed effects models accounted for dependencies associated with the repeated observations of measured variables on reefs over time. Fitted models included fixed effects for differences in cover between sectors, between years and the interaction between sector and year. Variation between reefs within sectors was fitted as a random effect. Where there were significant differences among years or between sectors, pair-wise multiple comparisons (Bonferroni-adjusted) were used to test specific a posteriori hypotheses about the temporal changes in the response. The models were fitted using the MIXED command in the SPSS (Norusis 2006).

Multivariate Regression Trees (MRT; De'ath 2002) were used to assess relationships between the multivariate fish assemblages (based on both species abundances and abundances of trophic groups) and measures of benthic cover over time. Estimates of percent cover of the following benthic life forms were included in this analysis: branching, tabulate, digitate, encrusting, submassive and bottlebrush Acropora spp. and branching, encrusting, foliose, massive and submassive corals belonging to other families, Fungiid corals, coralline, turf and macro algae, soft corals and sponges. Dissimilarity measures of the fish community were partitioned according to changes in the percent cover of benthic groups. This approach highlights significant changes in the fish communities through time that were associated with changes in the benthic community. The groupings of years identified by MRT as having similar fish communities based on benthic cover were overlaid onto a principal components analysis (PCA) biplot using convex hulls. These biplots represented changes in fish community structure across reefs and years, and the hulls highlighted the importance of changes in benthic cover to temporal patterns. The data were transformed and standardized using the Hellinger metric (Rao 1995, Legendre \& Gallagher 2001) prior to analysis. The Hellinger metric standardizes the data to a measure of relative abundance (i.e. row standardized), reducing the influence of very abundant species. The percent variation in fish community composition that was explained independently by variation in components of benthic cover was calculated using Euclidean-based Redundancy Analysis (van den Wollenberg 1977, Legendre \& Gallagher 2001).

\section{RESULTS}

\section{Trends in coral cover and reef slope complexity}

In 1993, mean coral cover on the reefs in the CL sector was $14 \%$ (Fig. 2), having decreased from $~ 30 \%$ in 1985 to 1986 (LTMP unpubl. data). Despite the removal of most live hard coral and dead coral rubble by heavy wave action, overall topographic complexity on the slopes of these reefs was moderate at the start of surveys because of the rugosity of the underlying substrate (Fig. 3). Complexity increased as re-growth of coral colonies provided extra relief (Figs. $3 \& 4$ ). Mean

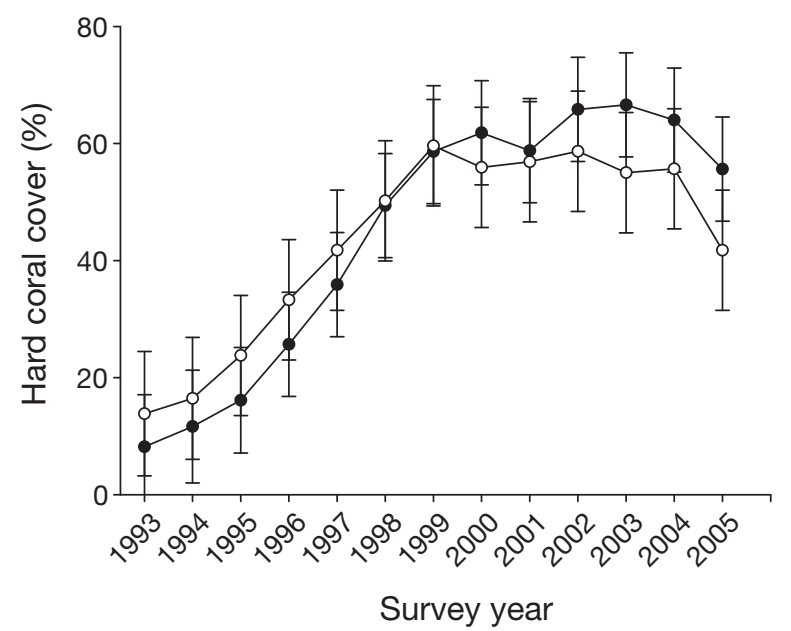

Fig. 2. Mean total hard coral cover 1993 to 2005 in the Cooktown/Lizard Island ( $($ ) and the Capricorn/Bunker $(\bullet)$ sectors. Error bars are $95 \%$ CIs 

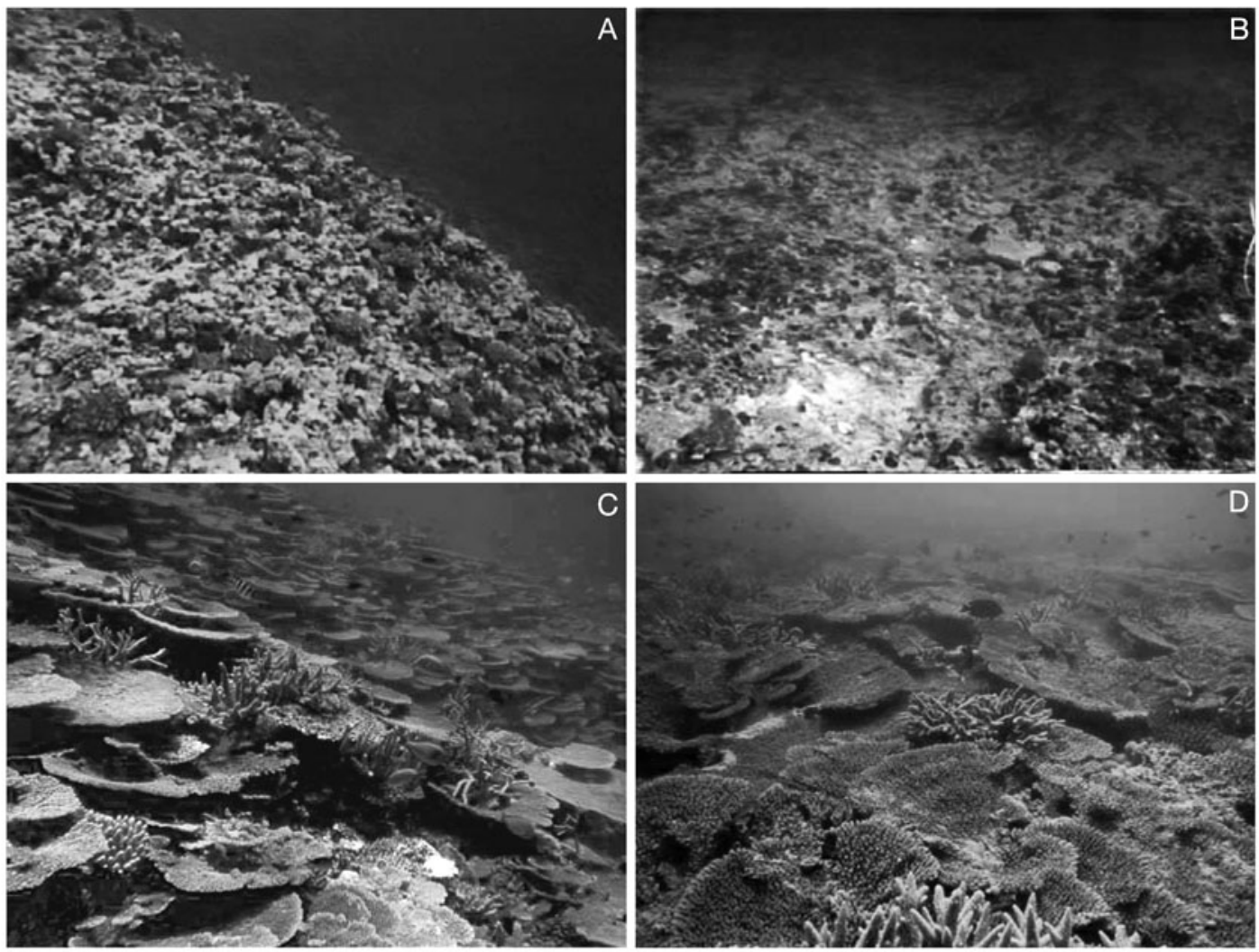

Fig. 3. Pre- and post-recovery photographs of reefs in each sector highlighting the difference in topographic complexity of the reef slope. (A,C) Cooktown/Lizard sector reef slope in (A) 1993 (topographic complexity score = 2) and (C) 2003 (topographic complexity score $=4)$. (B,D) Capricorn/Bunker sector reef slop in (B) 1993 (topographic complexity score =1) and (D) 2003 (topographic complexity score $=4)$. For alll panels, the photographer was roughly the same distance above the substrate $(\sim 1$ to $2 \mathrm{~m})$

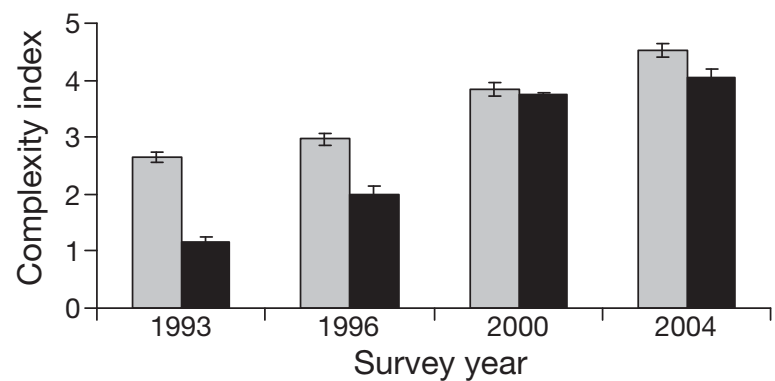

Fig. 4. Mean index of topographical complexity in the Cooktown/Lizard Island (grey) and the Capricorn/Bunkers (black) sectors. Error bars are $95 \%$ CIs

coral cover in the CB sector in 1993 was $8 \%$ (Fig. 2) after a dramatic decline from $~ 80 \%$ in the late 1980 s (Halford et al. 2004). Heavy wave action removed the coral colonies from these reefs leaving flat, featureless terraces, devoid of rubble and with occasional shallow gullies (Fig. 3). Because of this, topographic complexity on reef slopes in the CB sector was very low in the initial surveys (Fig. 4), but was high by the end of the surveys (Fig. 4) because of the increase in relief provided by re-growth of coral colonies. Importantly, topographic complexity in 1993 was significantly higher in the CL sector than CB (Fig. $4 ; F_{1,20}=78.050, \mathrm{p}<0.001$ ), though coral cover was similarly low in both sectors. By 2000, complexity in the CB sector had increased to levels similar to CL (Fig. $4 ; F_{1,20}=0.313, \mathrm{p}=0.582$ ). Although complexity was again higher in the CL sector by $2004\left(F_{1,20}=7.921, \mathrm{p}=0.011\right)$, the difference was small and unlikely to be ecologically significant (Fig. 4).

\section{Recovery of the benthic communities}

Hard coral cover recovered at a similar rate in both sectors (Table 1, Fig. 2), mainly due to the recruitment and growth of tabulate corals such as Acropora hyacinthus and A. cytherea, but the coral cover reached different levels in the 2 sectors. In 2003 and 2004, mean cover of tabulate Acropora spp. was 50 to $55 \%$ in the CB sector but only 25 to $30 \%$ in the CL (Fig. 5A). Cover of tabulate Acropora spp. (and total hard coral cover) was relatively stable 1999 to 2004 . 
Table 1. Fixed effects from linear mixed model analysis for each benthic variable. Bold: significant $(\alpha=0.05)$

\begin{tabular}{|lccrr|}
\hline Variable & Source & df & $F$ & $\mathrm{p}$ \\
\hline Total hard coral & Sector & $1,6.5$ & 0.2 & 0.656 \\
& Visit & $12,31.7$ & 25.3 & $<\mathbf{0 . 0 0 1}$ \\
& Sector $\times$ visit & $12,31.7$ & 2.6 & $\mathbf{0 . 0 1 6}$ \\
Tabulate & Sector & $1,6.1$ & 6.7 & $\mathbf{0 . 0 4 1}$ \\
Acropora spp. & Visit & $12,35.4$ & 18.9 & $<\mathbf{0 . 0 0 1}$ \\
& Sector $\times$ visit & $12,35.3$ & 2.3 & $\mathbf{0 . 0 2 7}$ \\
Branching & Sector & $1,5.3$ & 0.1 & 0.725 \\
Acropora spp. & Visit & $12,38.0$ & 38.1 & $<\mathbf{0 . 0 0 1}$ \\
& Sector $\times$ visit & $12,38.9$ & 3.7 & $\mathbf{0 . 0 0 1}$ \\
Coralline algae & Sector & $1,9.0$ & 23.1 & $\mathbf{0 . 0 0 1}$ \\
& Visit & $12,30.1$ & 19.3 & $<\mathbf{0 . 0 0 1}$ \\
& Sector $\times$ visit & $12,29.8$ & 5.6 & $<\mathbf{0 . 0 0 1}$ \\
Turf algae & Sector & $1,6.9$ & 11.2 & $\mathbf{0 . 0 1 3}$ \\
& Visit & $12,48.9$ & 22.9 & $<\mathbf{0 . 0 0 1}$ \\
& Sector $\times$ visit & $12,48.2$ & 4.0 & $<\mathbf{0 . 0 0 1}$ \\
\hline
\end{tabular}

Cover of branching Acropora spp. increased in both sectors in a similar linear fashion (Fig. 5B) 1999 to 2004, but declined by $\sim 2 \%$ in the CL sector in 2005 (Bonferroni multiple pair-wise comparison: mean difference $=$ $-11.5, \mathrm{p}<0.001, \mathrm{df}=52.75$; Fig. 5B), resulting in a significant sector by visit interaction (Table 1). All other hard coral life form categories occurred in low abundance and varied little through time (Fig. 5C-F). For this reason they were excluded from further analysis.

Changes in cover of coralline and turf algae differed between the sectors (Table 1): cover of coralline algae in the $\mathrm{CB}$ sector showed some inter-annual variability but no overall trend, while the cover on reefs in the CL sector declined from 1993 to 1999 (Fig. 5G). Turf algae declined in both sectors from high levels in 1993 to lows in 1999 (Fig. 5H), but initial cover of turf algae was higher in the $\mathrm{CB}$ sector, and the decline was greater. Turf algal cover stabilized in both sectors after 1999 (Fig. 5H).

Percent cover of branching and of tabulate Acropora spp. were the best predictors of change in fish community structure, and cover of coralline and turf algae also explained some variation (Table 2). Fifteen other benthic cover variables were assessed but did not explain significant variation in fish community composition and are not presented here.

\section{Response of the fish communities}

The MTR analysis identified 4 types of fish communities associated with successive stages of coral recovery in the CB sector: (1) 1993 to 1995 coral cover was low (cover of branching Acropora spp. $<2.60 \%$, tabulate Acropora spp. <4.19\%); (2) 1995 to 1998, (branch-
Table 2. Percent variation in fish community composition explained by benthic variables in the Cooktown-Lizard Island (CL) and Capricorn-Bunkers (CB) sectors estimated using redundancy analyses. (Total HC = total hard coral cover, $\mathrm{ACB}=$ branching Acropora spp., ACT = tabulate Acropora spp., $\mathrm{CA}=$ coralline algae, $\mathrm{TA}=$ turf algae $)$

\begin{tabular}{|ccrr|}
\hline & Variable & CL & CB \\
\hline Species abundance & Total HC & 14.5 & 22.2 \\
& ACB & 18.7 & 26.4 \\
& ACT & 10.1 & 18.1 \\
& ACB + ACT & 17.3 & 33.7 \\
& CA & 6.1 & 8.3 \\
& TA & 6.1 & 13.1 \\
Trophic abundance & Total HC & 38.8 & 52.6 \\
& ACB & 50.9 & 45.9 \\
& ACT & 24.9 & 43.3 \\
& ACB + ACT & 53.6 & 60.9 \\
& CA & 12.9 & 11.1 \\
& TA & 15.7 & 33.8 \\
\hline
\end{tabular}

ing Acropora spp. $<2.60 \%$ and tabulate Acropora spp. $>4.19 \%$ ); (3) 1998 to 2001, (branching Acropora spp. 2.60 to $5.13 \%$ ) and (4) 2001 to 2005 (branching Acropora spp. $>5.13 \%$ ) (Fig. 6). When coral cover was very low, a single damselfish species Pomacentrus coelestis made up $95 \%$ of recorded individuals. The number of species began to increase between 1995 and 1998 as coral-associated species such as the butterflyfishes Chaetodon plebius and Chaetodon trifascialis and herbivores such as Scarus globiceps and Chlorurus sordidus appeared on the reefs (Fig. 6). By 2001 to 2005 these and other species characterized the community, while numbers of $P$. coelestis had declined. The number of species continued to increase, and species that live in close association with living corals such as the damselfishes Plectroglyphidodon dickii and Pomacentrus moluccensis increased in abundance (Fig. 6). From 2001 until 2005 species such as Chromis atripectoralis and Dascyllus reticulatus appeared on the reefs, 2 planktivores that mainly use live branching Acropora spp. for shelter. Changes in cover of tabulate and of branching Acropora spp. together accounted for $60 \%$ of the variation in fish trophic groups, while $53 \%$ of that variation was associated with change in total hard coral cover (Table 2).

In the CL sector, the MTR analysis identified a shift from one distinct fish community to another as the benthic community recovered: the first occurred from 1993 to 1997 when coral cover was low $(<3.3 \%$ branching Acropora spp.) and the second from 1998 to 2005 when coral cover was higher ( $>3.3 \%$ branching Acropora spp.; Fig. 7). Initially the fish community included many species in low abundance, most notably the damselfishes Pomacentrus coelestis and Stegastes fasciolatus. The herbivores Ctenochaetus spp. and Acan- 

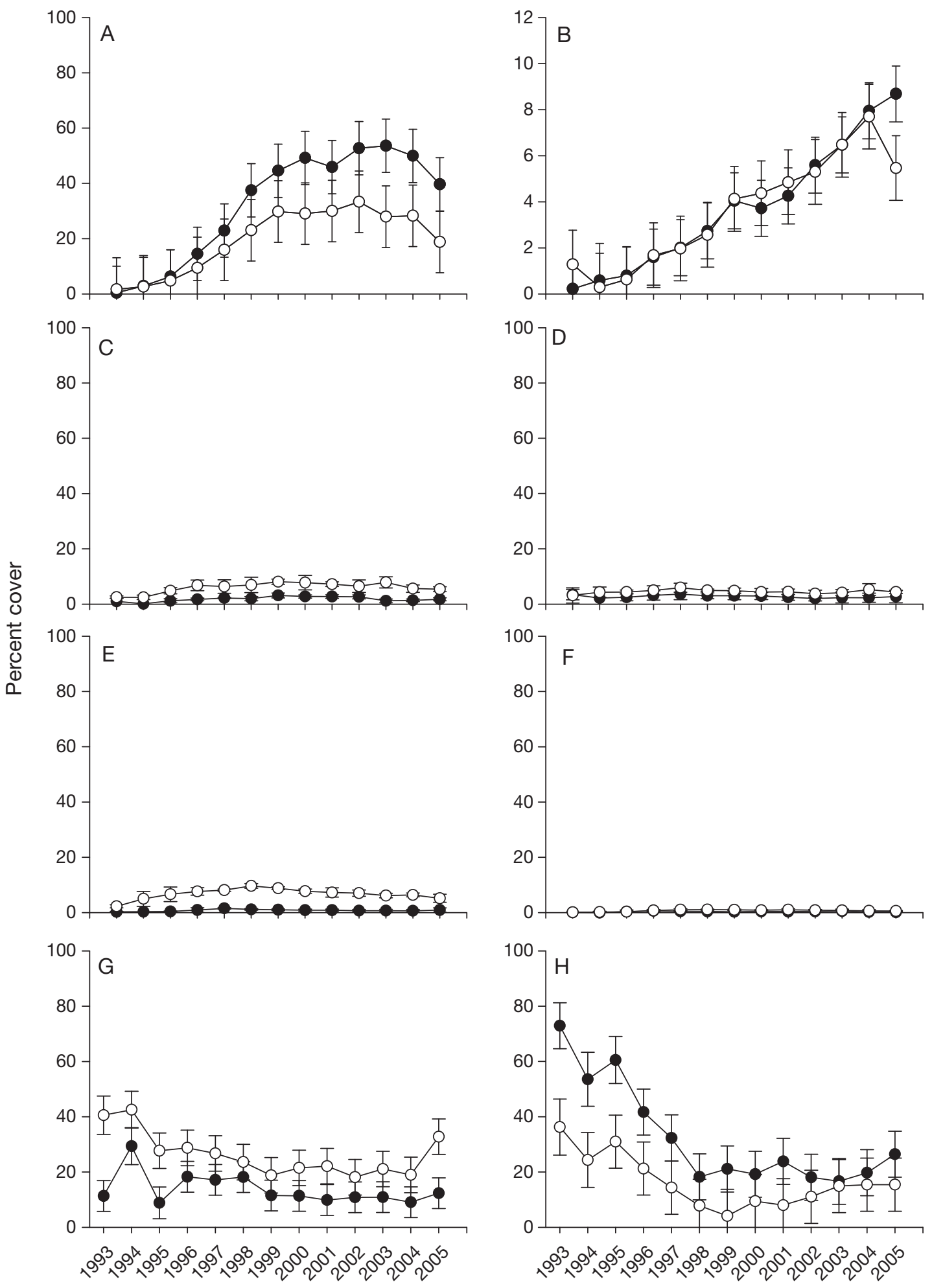

Survey year

Fig. 5. Mean percent cover of benthic organisms on reefs in the Cooktown/Lizard Island (O) and Capricorn/Bunker $(\bullet)$ sectors 1993 to 2005. (A) tabulate Acropora spp.; (B) branching Acropora spp.; (C) other Acropora spp. (including bottlebrush, digitate, encrusting and submassive life forms); (D) encrusting non-Acropora spp.; (E) submassive non-Acropora spp.; (F) other nonAcropora spp. (including branching, foliose, massive lifeforms and fungiids); (G) coralline algae and (H) turf algae. Error bars are $95 \%$ CIs 


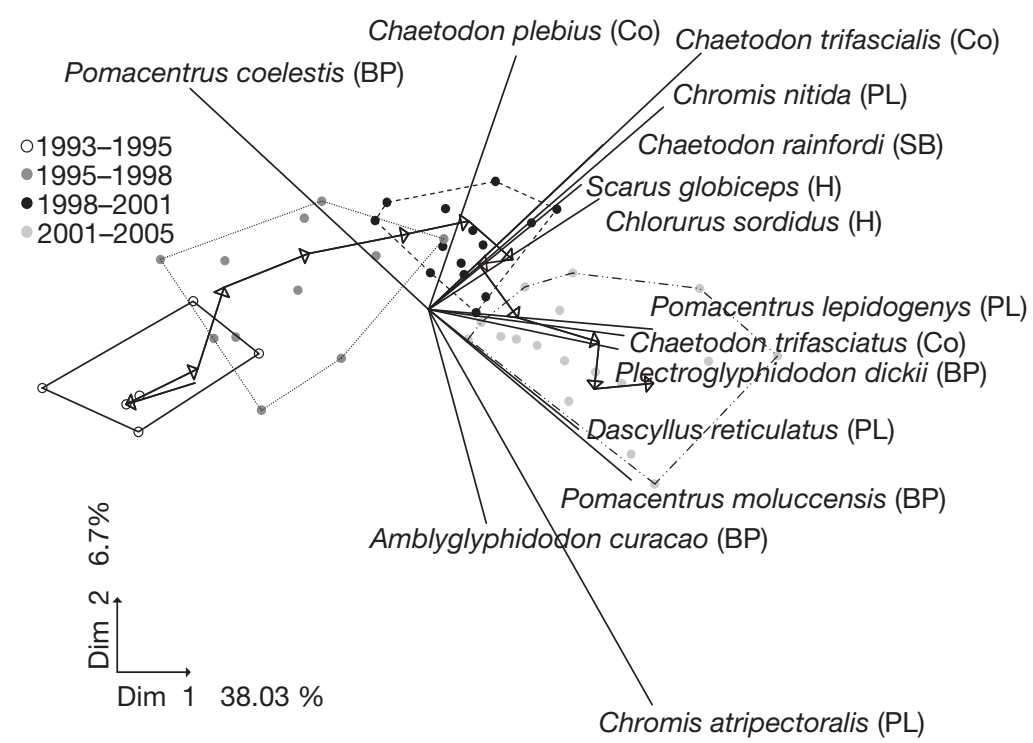

Fig. 6. Principal components biplot based on the relative abundance of fishes in the Capricorn/Bunkers sector over time showing the change in community composition as the coral recovered. Encircled points: 4 classes of fish communities on reefs at different stages of recovery of the benthic community as identified by a regression tree analysis. Each point represents a single reef in a single year. Vectors give the direction and relative magnitude of variability in abundance of the top $10 \%$ of species contributing to the variation in the multivariate assemblage. Letters in parentheses after species names: trophic group to which they belong: $\mathrm{H}=$ herbivores, $\mathrm{Bp}=$ benthic planktivores, $\mathrm{Co}=$ corallivores, $\mathrm{PL}=$ planktivores and $\mathrm{SB}=$ sessile benthic feeders. Arrows indicate the trajectory of the annual centroid 1993 to 2005, such that the first arrow represents the change from 1992 to 1993, the second arrow represents the change from 1993 to 1994, through to the final arrow representing change in the final year (2004 to 2005)

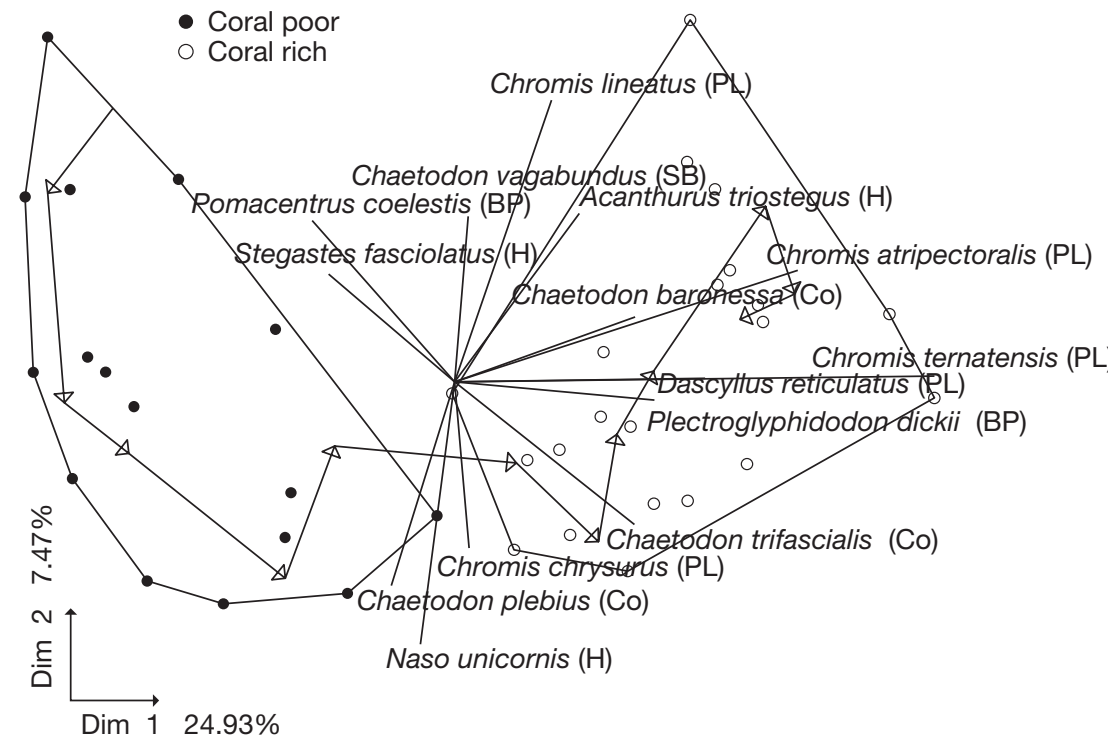

Fig. 7. Principal components biplot of the relative abundance of fishes on Cooktown/Lizard Island reefs over time showing shifts in community composition associated with the coral community succession (same organization and species abbreviations as in Fig. 6) thurus nigrofuscus were also abundant during this period. As coral cover increased, many of these species declined in abundance, whilst the abundances of coral-associated species such as various Chaetodon spp. increased. By the time coral cover was high, there were numerous abundant damselfishes, most notably the planktivorous Chromis species such as $C$. ternatensis and C. atripectoralis and the coral-dwelling damselfish Plectroglyphidodon dickii. Changes in cover of branching Acropora spp. explained $51 \%$ of the variation in fish trophic groups (Table 2). Inclusion of the cover of tabulate Acropora spp. only explained a further $3 \%$ of the variation (Table 2).

The fish communities in each sector were quite different immediately following the initial disturbances, but their trophic structure became similar as hard coral recovered. At certain times there was significant variation between the sectors in both species richness (Visit $\times$ Sector interaction $\left.F_{1,12}=3.744, \mathrm{p}=0.001\right)$ and total abundance (Visit $\times$ Sector interaction $F_{1,12}=$ $6.824, \mathrm{p}<0.001)$. Most notably, species richness remained stable in the CL sector but increased markedly in the $\mathrm{CB}$ sector (Fig. 8). When coral cover was low, the fish communities in the CB sector were dominated by one abundant species, Pomacentrus coelestis, and total species richness was about half that of the CL (Fig. 8). By 2005, species richness in the CB sector had reached levels similar to those in the CL. Total abundance was more variable than species richness in both sectors. The temporal profiles of total fish abundance were remarkably similar in both sectors, and the significant interaction term was due mainly to disparities in a few years at the start and end of the study period (Fig. 8).

The trophic structure of fish communities in the 2 sectors differed initially after the disturbances, but was similar by the end of the study (Fig. 9). Four of the 6 trophic groups differed in both relative abundance and species richness at the start of the study, whilst only 2 of the trophic groups differed in these 


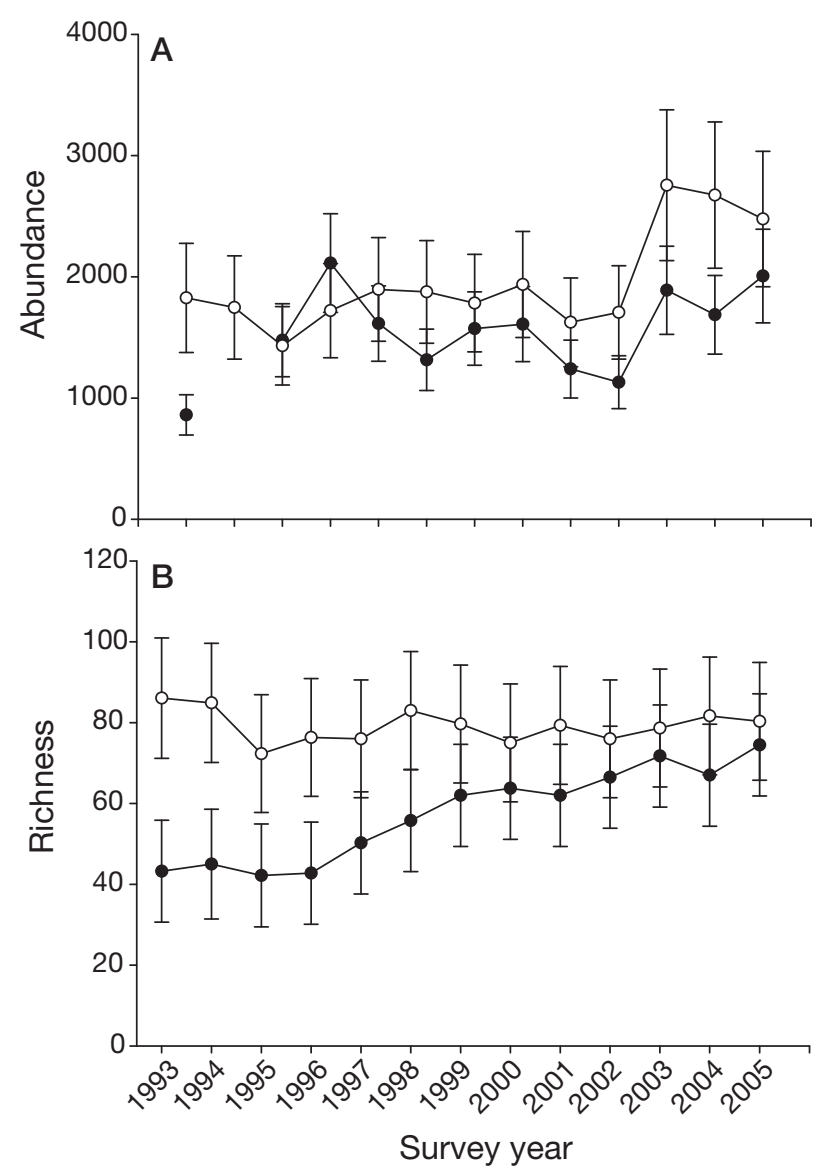

Fig. 8. Fish communities in the Cooktown/Lizard Island (O) and the Capricorn/Bunkers (•) sectors 1993 to 2005. (A) total abundance of fishes (up to $210 \mathrm{spp}$.), (B) constrained species richness (up to 210 spp.). Error bars are $95 \%$ CIs

metrics by the end of the study. There was a significant Sector $\times$ Visit interaction term for all trophic groups except planktivores in relative abundances and all groups but planktivores and sessile benthic feeders in species richness (Table 3 ). The relative abundances of 4 of the 6 trophic groups differed between sectors in the first year of the study (benthic planktivores $\mathrm{p}<$ 0.001 , herbivores $p<0.001$, planktivores $p=0.003$ and predators $p=0.027$; Fig. 9). However, by the final year of the study the relative abundances of 3 of the 4 groups were similar in the 2 sectors (benthic planktivores $\mathrm{p}=0.344$, herbivores $\mathrm{p}=0.255$ and predators $\mathrm{p}=$ 0.979; Fig. 9). The relative abundance of planktivores remained significantly different throughout the study period (Table 3 ). The relative abundance of corallivores was initially similar $(p=0.223$; Fig. 9), but diverged in $1998(p=0.012)$ and remained different for the duration of the study. In the first year of the study, species richness of corallivores $(p<0.001)$, herbivores $(p=0.002)$ and predators $(p=0.001)$ differed between the sectors, but attained similar richness by 2005 (corallivores, $\mathrm{p}=0.787$; herbivores, $\mathrm{p}=0.394$; predators, $\mathrm{p}=0.308$; Fig. 9). Benthic planktivores only substantially differed between the sectors in 2005 ( $p<$ 0.001; Fig. 9). Planktivores retained differences in species richness between sectors throughout the study (Table 3), and sessile benthic feeder richness did not differ between the sectors (Table 3).

\section{DISCUSSION}

Severe storm damage in 2 distant regions had quite different initial effects on the structure of fish communities on reefs where slopes had been dominated by tabulate Acropora spp. Shortly after the disturbance, species richness was much lower in the CB sector than the $\mathrm{CL}$, and some trophic groups were underrepresented. Storms are unlikely to have caused declines in numbers of fishes and in species richness through direct mortality (Harmelin-Vivien 1994) or by a lack of potential recruits in the years following disturbance (Halford et al. 2004). Wave action removed most of the living coral colonies in both sectors, but a salient difference between reefs in the 2 locations was the rugosity of the underlying calcareous reef substrate (substrate complexity), which was flat on southern reefs but more complex and rugose in the northern sector. We suspect that the particularly low topographic complexity in the CB sector provided inadequate shelter for many species, leading to lower abundance and diversity (Almany 2004, Dominici-Arosemena \& Wolff 2005, Garpe et al. 2006). Without cover and refuges, the risk of predation would have increased, and competition for available shelter would have intensified. The fate of these fishes is unknown: they may have died or have moved to other parts of the same reef or into deeper water where suitable shelter and habitat could still be found (e.g. Kaufman 1983, Walsh 1983). This did not apply in the CL sector because the higher substrate complexity of these reefs meant that they were able to provide shelter and habitat, despite the loss of living coral.

The fish communities became similar in the 2 sectors as the coral recovered, because the new coral colonies increased the topographic complexity in the CB sector and provided habitat for species that depend on living coral on reefs in both sectors. This increasing similarity of relative abundance of fishes in the 2 sectors as coral communities recovered was reflected in 4 of the 6 trophic groups (benthic planktivores, herbivores, predators and sessile benthic feeders). Species richness and relative abundance of planktivores remained much higher in the CL sector over time. This may reflect latitudinal and biogeographical differences in the species pools brought about by differences in the reef slope angle and oceanographic characteristics. The reefs in 
Relative Abundance

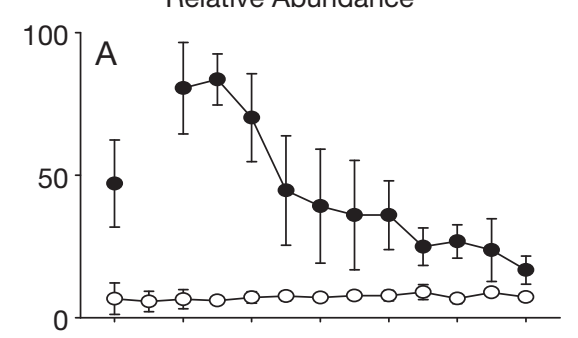

100 ]
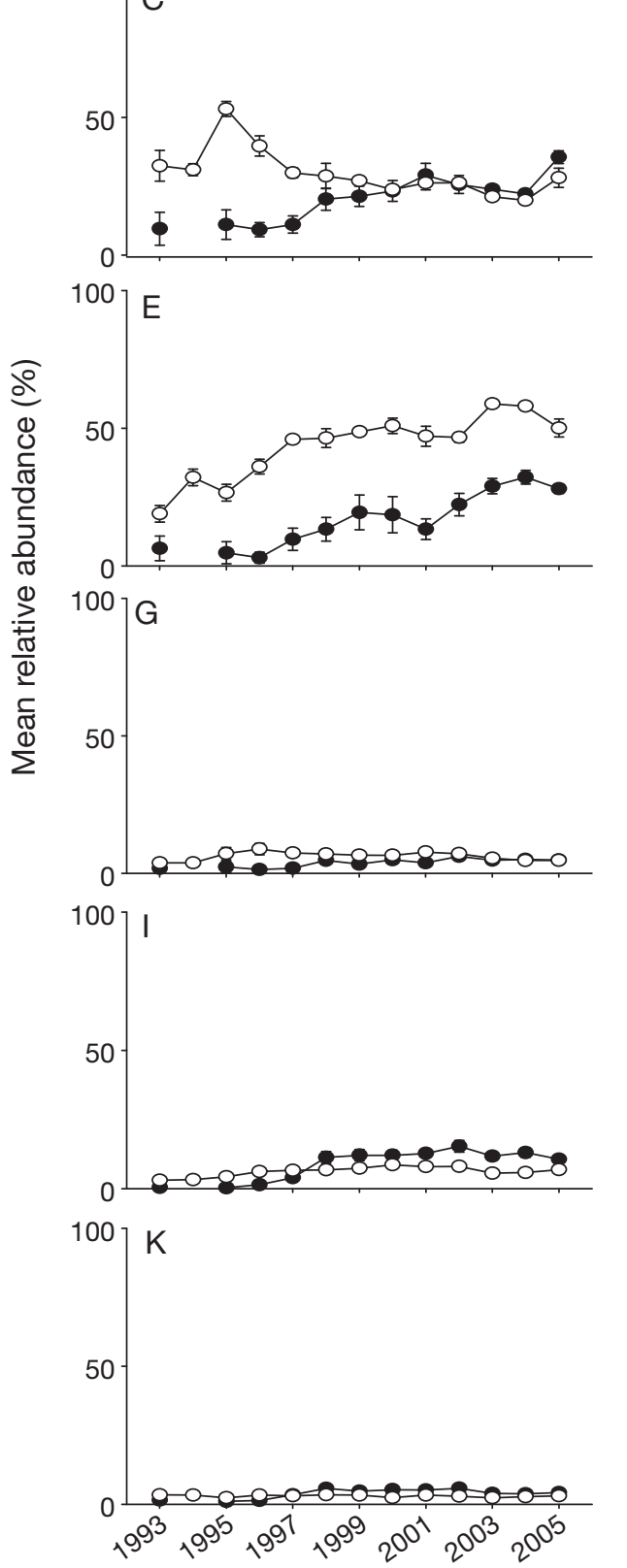

Species Richness

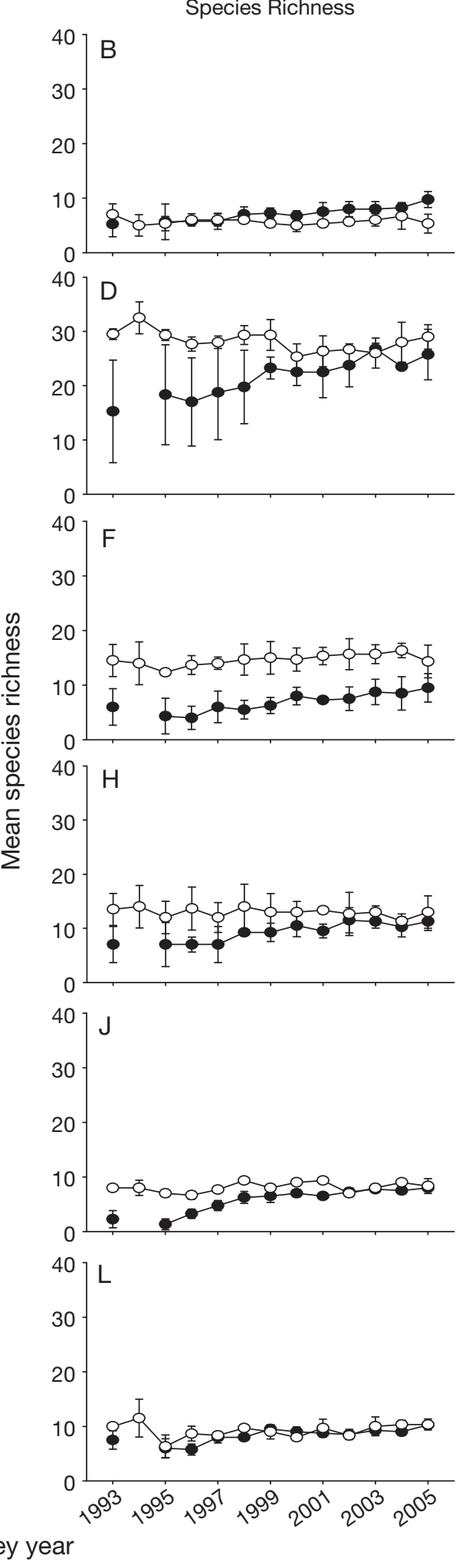

Fig. 9. Trophic structure of fish communities in the Cooktown/Lizard Island (O) and the Capricorn/Bunkers (•) sectors 1993 to 2005. Relative abundance (left column) and constrained species richness (right column) of 6 trophic groups of fishes. (A,B) benthic planktivores; $(\mathrm{C}, \mathrm{D})$ herbivores; $(\mathrm{E}, \mathrm{F})$ planktivores; $(\mathrm{G}, \mathrm{H})$ predators; $(\mathrm{I}, \mathrm{J})$ corallivores; and $(\mathrm{K}, \mathrm{L})$ sessile benthic feeders. Error bars are $95 \%$ CIs 
Table 3. Fixed effects from linear mixed model analysis for each reef fish trophic group. Bold: significant ( $\alpha=0.05)$

\begin{tabular}{|c|c|c|c|c|c|c|c|}
\hline \multirow[t]{2}{*}{ Variable } & \multirow[t]{2}{*}{ Source } & \multicolumn{3}{|c|}{ - Abundance - } & \multicolumn{3}{|c|}{ - Species richness - } \\
\hline & & df & $F$ & $\mathrm{p}$ & $\mathrm{df}$ & $F$ & $\mathrm{p}$ \\
\hline \multirow{3}{*}{$\begin{array}{l}\text { Benthic } \\
\text { planktivores }\end{array}$} & Sector & 1,6 & 29.0 & 0.002 & 1,5 & 3.6 & 0.114 \\
\hline & Visit & 12,48 & 6.1 & $<0.001$ & 12,27 & 1.9 & 0.084 \\
\hline & Sector $\times$ visit & 12,47 & 5.0 & $<0.001$ & 12,27 & 2.5 & 0.025 \\
\hline \multirow[t]{3}{*}{ Corallivores } & Sector & 1,6 & 16.0 & 0.009 & 1,5 & 9.9 & 0.024 \\
\hline & Visit & 12,28 & 7.8 & $<0.001$ & 12,28 & 4.2 & 0.001 \\
\hline & Sector $\times$ visit & 12,28 & 4.4 & 0.001 & 12,28 & 2.5 & 0.027 \\
\hline \multirow[t]{3}{*}{ Herbivores } & Sector & 1,5 & 6.6 & 0.051 & 1,5 & 5.1 & 0.072 \\
\hline & Visit & 12,27 & 6.94 & $<0.001$ & 12,30 & 2.5 & 0.022 \\
\hline & Sector $\times$ visit & 12,28 & 8.6 & $<0.001$ & 12,31 & 2.3 & 0.034 \\
\hline \multirow[t]{3}{*}{ Planktivores } & Sector & 1,5 & 62.2 & $<0.001$ & 1,6 & 47.4 & 0.001 \\
\hline & Visit & 12,27 & 10.3 & $<0.001$ & 12,31 & 1.9 & 0.070 \\
\hline & Sector $\times$ visit & 12,28 & 1.6 & 0.165 & 12,31 & 1.7 & 0.135 \\
\hline \multirow[t]{3}{*}{ Predators } & Sector & 1,5 & 8.9 & 0.031 & 1,5 & 9.1 & 0.030 \\
\hline & Visit & 12,29 & 2.2 & 0.038 & 12,23 & 2.7 & 0.022 \\
\hline & Sector $\times$ visit & 12,30 & 4.2 & 0.001 & 12,22 & 2.7 & 0.021 \\
\hline \multirow{3}{*}{$\begin{array}{l}\text { Sessile benthic } \\
\text { feeders }\end{array}$} & C Sector & 1,10 & 8.8 & 0.014 & 1,5 & 1.0 & 0.358 \\
\hline & Visit & 12,43 & 3.5 & 0.001 & 12,26 & 2.6 & 0.019 \\
\hline & Sector $\times$ visit & 12,43 & 2.8 & 0.007 & 12,27 & 2.1 & 0.056 \\
\hline
\end{tabular}

Our analyses identified distinct fish communities associated with specific stages in the development of the coral community. The relative proportions of branching and tabulate Acropora spp. were identified as useful predictors of fish community structure. Other recent studies have also highlighted the importance of these coral groups to fish communities (Sano et al. 1987, Jones et al. 2004). These corals add a complex 3-dimensional structure in which fishes can shelter. Changes in cover of tabulate Acropora spp. explained more variation in the fish communities on reefs in the CB sector than in the CL. Tabulate Acropora spp. are fast-growing corals and contributed much of the early increase in topographic complexity in the CB sector. Since the reefs in the CL sector always retained some substrate complexity, this effect was less obvious. In contrast changes in the CL sector have very steep slopes and are prone to upwellings of nutrient-rich waters (Revelante et al. 1982, Furnas \& Mitchell 1986). These conditions are ideal for the maintenance of a diverse and speciose planktivorous community, and indeed more planktivorous species occur on outer reefs in the northern GBR than in the south (AIMS LTMP unpubl. data). The divergence in relative abundance of corallivores between sectors was largely driven by a large increase in abundance of a single species, Chaetodon trifascialis, in the CB sector. This species is one of the most specialized feeders of all fishes, preying only on a few species of tabulate Acropora (Pratchett 2007). These corals occurred in greater abundance in the CB sector, which would account for the higher numbers of this species in particular and corallivores in general that were found in that sector.

The differing response of herbivorous fishes in the 2 sectors suggests a potential mechanism for the increasing similarity of the fish communities. The abundance and species richness of herbivorous fishes was low in the CB sector prior to 1996 despite the abundant turf algae, but coral cover and reef surface complexity were low, so the lack of shelter probably limited exploitation of this food resource. In contrast, numbers of herbivorous fishes were relatively high in the CL sector in the early years of the study when living coral cover was at its lowest, then declined as the algal cover declined. This suggests that the substrate complexity on the reef slopes in the CL sector provided sufficient shelter for fishes to access the abundant algae, a distinction that decreased in extent as the coral recovered. cover of branching Acropora spp. explained much of the variation in abundance of fishes by fish trophic group in both $\mathrm{CB}$ and $\mathrm{CL}$ sectors over the period of recovery. This is likely because a number of coral-associated species depend particularly on branching Acropora spp. for food or shelter (Jones et al. 2004).

The recent literature concerning the state of coral reefs is mostly based on short or intermittent time scales, limited by the time scale for academic funding (HoeghGuldberg 1999, Goreau et al. 2000, Bellwood et al. 2004, Jones et al. 2004, Garpe et al. 2006, Graham et al. 2006). Coral reefs are dynamic systems that are frequently affected by various forms of disturbance (Connell 1978, Hughes \& Jackson 1985, Hughes 1989, Done 1992, Bythell et al. 2000, Kleypas \& Eakin 2007), but corals grow slowly relative to the duration of research grants: even fast-growing corals such as tabulate Acropora spp. may take a decade or longer to recover. As such, many time series are not long enough to document if and how reefs recover. The benefit of the present study is its long time span, which shows these coral reefs as dynamic systems, undergoing both disturbance and recovery. However, both sectors in the present study are well offshore and remote from centres of population and coastal influences. Coral reefs in many parts of the tropics suffer a wider range of anthropogenic insults. Australia's Great Barrier Reef may represent an unusually favourable case in terms of reef recovery and resilience. The present study has shown that reefs that maintain functionally similar fish communities, despite some variation due to their regional settings. recover from disturbance to similar benthic communities 
Acknowledgements. We thank the crews of the AIMS research vessels, the Cape Ferguson and Lady Basten. G. P. Jones, P. Munday and 3 anonymous reviewers provided suggestions on the manuscript. Funding was provided by AIMS, the Australian Government's Marine and Tropical Sciences Research Centre and the Cooperative Research Centre for the Great Barrier Reef World Heritage Area.

\section{LITERATURE CITED}

Adjeroud M, Augustin D, Galzin R, Salvat B (2002) Natural disturbances and interannual variability of coral reef communities on the outer slope of Tiahura (Moorea, French Polynesia):1991 to 1997. Mar Ecol Prog Ser 237:121-131

> Adjeroud M, Chancerelle Y, Schrimm M, Perez T, Lecchini D, Galzin R, Salvat B (2005) Detecting the effects of natural disturbances on coral assemblages in French Polynesia: a decade survey at multiple scales. Aquat Living Resour 18:111-123

> Almany GR (2004) Differential effects of habitat complexity, predators and complexity on abundance of juvenile and adult coral reef fishes. Oecologia 141:105-113

Bellwood DR, Choat JH (1990) A functional analysis of grazing in parrotfishes (family Scaridae): the ecological implications. Environ Biol Fishes 28:189-214

Bellwood DR, Hughes TP, Folke C, Nystroem M (2004) Confronting the coral reef crisis. Nature 429:827-833

Berkelmans R, Oliver JK (1999) Large scale bleaching of the Great Barrier Reef. Coral Reefs 18:55-60

Berumen M, Pratchett M (2006) Recovery without resilience: persistent disturbance and long term shifts in the structure of fish and coral communities at Tiahura Reef, Moorea. Coral Reefs 25:647-653

Booth DJ, Beretta GA (2002) Changes in a fish assemblage after a coral bleaching event. Mar Ecol Prog Ser 245: 205-212

Bozec YM, Doledec S, Kulbicki M (2005) An analysis of fishhabitat associations on disturbed coral reefs. J Fish Biol 66: 966-982

Bythell JC, Hillis-Starr ZM, Rogers CS (2000) Local variability but landscape stability in coral reef communities following repeated hurricane impacts. Mar Ecol Prog Ser 204: 93-100

Cheal AJ, Coleman G, Delean S, Miller I, Osborne K, Sweatman H (2002) Responses of coral and fish assemblages to a severe but short-lived tropical cyclone on the Great Barrier Reef, Australia. Coral Reefs 21:131-142

Colgan MW (1981) Succession and recovery of a coral after predation by Acanthaster planci (L.). Proc 4th Int Coral Reef Symp 2:333-338

Collins SL, Glenn SM, Gibson DJ (1995) Experimental analysis of intermediate disturbance and initial floristic composition: decoupling cause and effect. Ecology 76:486-492

- Connell JH (1978) Diversity in tropical rain forests and coral reefs. Science 199:1302-1309

> Cowen RK, Paris CB, Srinivasan A (2006) Scaling of connectivity in marine populations. Science 311:522-527

De'ath G (2002) Multivariate regression trees: a new technique for constrained classification analysis. Ecology 83: $1103-1117$

Dominici-Arosemena A, Wolff M (2005) Reef fish community structure in Bocas del Toro (Caribbean, Panama): gradients in habitat complexity and exposure. Caribb J Sci 41:613-637

Done TJ (1992) Constancy and change in some Great Barrier Reef coral communities: 1980-1990. Am Zool 32:655-662
Edmunds PJ, Carpenter RC (2001) Recovery of Diadema antillarum reduces macroalgal cover and increases abundance of juvenile corals on a Caribbean reef. Proc Natl Acad Sci USA 98:5067-5071

Froese R, Pauly D (eds) (2006) FishBase. Available at www. fishbase.org

> Furnas MJ, Mitchell AW (1986) Phytoplankton dynamics in the central Great Barrier Reef. I. Seasonal changes in biomass and community structure and their relation to intrusive activity. Cont Shelf Res 6:363-384

> Gardner TA, Cote IM, Gill JA, Grant A, Watkinson AR (2005) Hurricanes and Caribbean coral reefs: impacts, recovery, patterns and role in long-term decline. Ecology 86: $174-184$

> Garpe KC, Yahya SAS, Lindahl U, Öhman MC (2006) Longterm effects of the 1998 coral bleaching event on reef fish assemblages. Mar Ecol Prog Ser 315:237-247

> Goreau T, McClanahan T, Hayes R, Strong A (2000) Conservation of coral reefs after the 1998 global bleaching event. Conserv Biol 14:5-15

Graham NAJ, Wilson SK, Jennings S, Polunin NVC, Bijoux JP, Robinson J (2006) Dynamic fragility of oceanic coral reef ecosystems. Proc Natl Acad Sci USA 103:8425-8429

Halford A, Cheal AJ, Ryan D, Willams DM (2004) Resilience to large-scale disturbance in coral and fish assemblages on the Great Barrier Reef. Ecology 85:1892-1905

Harmelin-Vivien ML (1994) The effects of storms and cyclones on coral reefs: a review. J Coast Res 12(Spec Issue):211-231

- Hiura T (1995) Gap formation and species diversity in Japanese beech forests: a test of the intermediate disturbance hypothesis on a geographic scale. Oecologia 104:265-271

- Hoegh-Guldberg O (1999) Climate change, coral bleaching and the future of the world's coral reefs. Mar Freshw Res 50:839-866

- Hughes TP (1989) Community structure and diversity of coral reefs: the role of history. Ecology 70:275-279

Hughes TP, Connell JH (1999) Multiple stressors on coral reefs: a long-term perspective. Limnol Oceanogr 44:932-940

Hughes TP, Jackson JBC (1985) Population dynamics and life histories of foliaceous corals. Ecol Monogr 55:141-166

Idjadi JA, Lee SC, Bruno JF, Precht WF, Allen-Requa L, Edmunds PJ (2006) Rapid phase-shift reversal on a Jamaican coral reef. Coral Reefs 25:209-211

James MK, Armsworth PR, Mason LB, Bode L (2002) The structure of reef fish metapopulation: modelling larval dispersal and retention patterns. Proc R Soc Lond B Biol Sci 269:2079-2086

Jones GP, Syms C (1998) Disturbance, habitat structure and the ecology of fishes on coral reefs. Aust J Ecol 23:287-297

Jones GP, McCormick MI, Srinivasan M, Eagle JV (2004) Coral decline threatens fish biodiversity in marine reserves. Proc Natl Acad Sci USA 101:8251-8253

$>$ Kaufman LS (1983) Effects of Hurricane Allen on reef fish assemblages near Discovery Bay, Jamaica. Coral Reefs 2:43-47

Kleypas JA, Eakin CM (2007) Scientists perceptions of the threats to coral reefs: results of a survey of coral reef researchers. Bull Mar Sci 80:419-436

Knowlton N (1992) Thresholds and multiple stable states in coral reef dynamics. Am Zool 32:674-682

Legendre P, Gallagher ED (2001) Ecologically meaningful transformations for ordination of species data. Oecologia 129:271-280

> Lewis AR (1997) Effects of experimental coral disturbance on the structure of fish communities on large patch reefs. Mar Ecol Prog Ser 161:37-50 
Lewis AR (1998) Effects of experimental coral disturbance on the population dynamics of fishes on large patch reefs. J Exp Mar Biol Ecol 230:91-110

Marshall PA, Baird AH (2000) Bleaching of corals on the Great Barrier Reef: differential susceptibilities among taxa. Coral Reefs 19:155-163

Moran P (1986) The Acanthaster phenomenon. Oceanogr Mar Biol Annu Rev 24:379-480

> Mumby PJ, Hastings A, Edwards HJ (2007) Thresholds and the resilience of Caribbean coral reefs. Nature 450: 98-101

Munday PL, Jones GP, Caley MJ (1997) Habitat specialization and the distribution and abundance of coral-dwelling gobies. Mar Ecol Prog Ser 152:227-239

Ninio R, Meekan MG (2002) Spatial patterns in benthic communities and the dynamics of a mosaic ecosystem on the Great Barrier Reef, Australia. Coral Reefs 21:95-103

Norusis M (2006) SPSS 15.0 guide to data analysis. Prentice Hall, Upper Saddle River, NJ

Pinheiro JC, Bates DM (2000) Mixed-effects models in S and S-Plus. Springer-Verlag, New York

Polunin NVC, Roberts CM (1993) Greater biomass and value of target coral-reef fishes in two small Caribbean marine reserves. Mar Ecol Prog Ser 100:167-176

Pratchett MS (2007) Dietary selection by coral-feeding butterflyfishes (Chaetodontidae) on the Great Barrier Reef, Australia. Raffles Bull Zool S14:171-176

Rao CR (1995) A review of canonical co-ordinates and an alternative to correspondence analysis using Hellinger distance. Qüestiió 19:23-63

Revelante NW, Williams WT, Bunt JS (1982) Temporal and spatial distributions of diatoms, dinoflagellates and Trichodesmium in waters of the Great Barrier Reef. J Exp Mar Biol Ecol 63:27-45

Sano M (2000) Stability of reef fish assemblages: responses to coral recovery after catastrophic predation by Acanthaster planci. Mar Ecol Prog Ser 198:121-130
Sano M, Shimizu M, Nose Y (1984) Changes in structure of coral reef fish communities by destruction of hermatypic corals: observational and experimental views. Pac Sci 38:51-80

Sano M, Shimizu M, Nose Y (1987) Long-term effects of destruction of hermatypic corals by Acanthaster planci infestation on reef fish communities at Iriomote Island, Japan. Mar Ecol Prog Ser 37:191-199

Sousa WP (1979) Experimental investigations of disturbance and ecological succession in a rocky intertidal algal community. Ecol Monogr 49:227-254

Syms C (1998) Disturbance and the structure of coral reef fish communities on the reef slope. J Exp Mar Biol Ecol 230: $151-167$

Syms C, Jones GP (2000) Disturbance, habitat structure, and the dynamics of a coral-reef fish community. Ecology 81:2714-2729

Underwood A (1999) Physical disturbances and their direct effect on an indirect effect: responses of an intertidal assemblage to a severe storm. J Exp Mar Biol Ecol 232: 125-140

van den Wollenberg AL (1977) Redundancy analysis. An alternative for canonical correlation analysis. Psychometrika 42:207-219

Walsh WJ (1983) Stability of a coral reef fish community following a catastrophic storm. Coral Reefs 2:49-63

Wilkinson C (2004) Status of coral reefs of the world: 2004. Australian Institute of Marine Science, Townsville

Wilson SK, Graham NAJ, Pratchett MS, Jones GP, Polunin NVC (2006) Multiple disturbances and the global degradation of coral reefs: are reef fishes at risk or resilient? Glob Change Biol 12:2220-2234

> Wilson SK, Graham NAJ, Polunin NVC (2007) Appraisal of visual assessments of habitat complexity and benthic composition on coral reefs. Mar Biol 151:1069-1076

Woodley JD, Chornesky EA, Clifford PA, Jackson JBC and others (1981) Hurricane Allen's impact on Jamaican coral reefs. Science 214:749-755 
Appendix 1. Long-term Monitoring Program species list and trophic group assignations

\begin{tabular}{|c|c|}
\hline Trophic group & Species \\
\hline Herbivores & $\begin{array}{l}\text { Acanthurus auranticavus, A. bariene, A. blochii, A. dussumieri, A. grammoptilus, A. nigroris, } \\
\text { A. olivaceus, A. xanthopterus, A. lineatus, A. maculiceps, A. nigricans, A. nigrofuscus, A. nigri- } \\
\text { cauda, A. pyroferus, A. triostegus, Calotomus carolinus, Cetoscarus bicolor, Chlorurus bleekeri, } \\
\text { C. japanensis, C. microrhinos, C. sordidus, Ctenochaetus binotatus, C. striatus, Dischistodus } \\
\text { melonotus, D. perspicillatus, D. prosopotaenia, D. pseudochrysopoecilus, Hemiglyphidodon } \\
\text { plagiometapon, Hipposcarus longiceps, Naso lituratus, N. tuberosus, N. unicornis, Plectroglyphi- } \\
\text { dodon lacrymatus, Pomacentrus adelus, P. chrysurus, P. grammorhynchus, P. tripunctatus, } \\
\text { P. wardi, Siganus argenteus, S. corallinus, S. doliatus, S. fuscescens, S. javus, S. lineatus, } \\
\text { S. punctatus, S. punctatissimus, S. spinus, S. vulpinus, Scarus altipinnis, S. chameleon, S. dimi- } \\
\text { diatus, S. flavipectoralis, S. forsteni, S. frenatus, S. ghobban, S. globiceps, S. longipinnis, S. niger, } \\
\text { S. oviceps, S. psittacus, S. rivulatus, S. rubroviolaceus, S. schlegeli, S. spinus, Stegastes apicalis, } \\
\text { S. fasciolatus, S. gascoynei, S. nigricans, Zebrasoma scopas, Z. veliferum }\end{array}$ \\
\hline Benthic planktivores & $\begin{array}{l}\text { Acanthochromis polyacanthus, Amblyglyphidodon curacao, A. leucogaster, Amphiprion akin- } \\
\text { dynos, A. clarkii, A. melanopus, A. percula, A. perideraion, Chrysiptera rex, Neoglyphidodon } \\
\text { nigroris, Plectroglyphidodon dickii, Pomacentrus amboinensis, P. australis, P. bankanensis, } \\
\text { P. brachialis, P. coelestis, P. moluccensis, P. nagasakiensis, P. vaiuli, Premnas biaculeatus }\end{array}$ \\
\hline Planktivores & $\begin{array}{l}\text { Acanthurus albipectoralis, A. thompsoni, A. mata, Hemitaurichthys polylepis, Paracanthurus } \\
\text { hepatus, Amblyglyphidodon aureus, Chromis acares, C. agilis, C. amboinensis, C. atripectoralis, } \\
\text { C. atripes, C. chrysura, C. flavomaculata, C. iomelas, C. lepidolepis, C. lineata, C. margaritifer, } \\
\text { C. nitida, C. retrofasciata, C. ternatensis, C. vanderbilti, C. viridis, C. weberi, C. xanthura, } \\
\text { Chrysiptera flavipinnis, C. rollandi, C. talboti, Dascyllus aruanus, D. reticulatus, D. trimaculatus, } \\
\text { Neoglyphidodon polyacanthus, Neopomacentrus azysron, N. bankieri, N. cyanomos, } \\
\text { Pomachromis richardsoni, Pomacentrus imitator, P. lepidogenys, P. philippinus }\end{array}$ \\
\hline Sessile benthic feeders & $\begin{array}{l}\text { Bolbometapon muricatum, Chaetodon auriga, C. citrinellus, C. ephippium, C. flavirostris, } \\
\text { C. kleinii, C. lineolatus, C. lunula, C. melannotus, C. mertensii, C. rafflesi, C. speculum } \\
\text { C. ulietensis, C. unimaculatus, C. vagabundus, Chelmon rostratus, Forcipiger flavissimus, } \\
\text { F. longirostris, Neoglyphidodon melas, Siganus puellus, Zanclus cornutus }\end{array}$ \\
\hline Corallivores & $\begin{array}{l}\text { Chaetodon aureofasciatus, C. baronessa, C. bennetti, C. meyeri, C. ornatissimus, C. pelewensis, } \\
\text { C. plebius, C. puntatofasciatus, C. rainfordi, C. reticulatus, C. trifascialis, C. trifasciatus, Cheilo- } \\
\text { prion labiatus, Plectroglyphidodon johnstonianus }\end{array}$ \\
\hline Predators & $\begin{array}{l}\text { Cheilinus fasciatus, C. undulatus, Choerodon fasciatus, Coris gaimard, Epibulus insidiator, } \\
\text { Gomphosus varius, Halichoeres hortulanus, Hemigymnus fasciatus, H. melapterus, Lethrinus } \\
\text { harak, L. atkinsoni, L. erythracanthus, L. laticaudis, L. lentjan, L. miniatus, L. nebulosus, } \\
\text { L. obsoletus, L. olivaceous, L. ornatus, L. rubrioperculatus, L. semicinctus, L. xanthochilus, } \\
\text { Lutjanus adetti, L. argentimaculatus, L. biguttatus, L. bohar, L. boutton, L. carponotatus, } \\
\text { L. fulviflamma, L. fulvus, L. gibbus, L. kasmira, L. lemniscatus, L. lutjanus, L. monostigma, } \\
\text { L. quinquelineatus, L. rivulatus, L. russelli, L. sebae, L. semicinctus, L. vitta, Macolor niger, } \\
\text { Monotaxis grandoculis, Plectropomus areolatus, P. laevis, P. leopardus, P. maculatus, Variola louti }\end{array}$ \\
\hline
\end{tabular}

Editorial responsibility: Charles Birkeland, Honolulu, Hawaii, USA
Submitted: February 6, 2008; Accepted: July 21, 2008

Proofs received from author(s): October 28, 2008 